\title{
REFLEKSI PERLINDUNGAN HUKUM TERHADAP PEKERJA ANAK BERWAWASAN GENDER
}

\author{
Oleh: \\ Nur Jannani \\ Uswatul Fikriyah
}

\begin{abstract}
Abstrak
Penelitian ini membahas mengenai permasalhaan perlindungan hukum terhadap pekerja anak di Indonesia yang sampai saat ini masih belum terimplementasi dengan baik meskipun telah banyak instrumen peraturan perundang- undangan yang memperhatikan tentang hak- hak anak. Dari hasil penelitian ini dapat diketahui bahwa perlindungan terhadap anak sebenarnya telah terintegrasi dalam hukum nasional yang terkandung dalam KUHPerdata, KUHPidana, dan sejumlah peraturan perundang- undangan tentang perlindungan anak. Sebagai upaya untuk menegakkan perlindungan hukum bagi pekerja anak setidaknya ada lima faktor yang harus dikuatkan yaitu diantaranya faktor hukum, faktor penegak hukum, faktor sarana dan fasilitas hukum, faktor masyarakat hukum, faktor budaya hukum.

Bentuk perlindungan hukum terhadap pekerja anak di Indonesia berwawasan gender selain sudah ada banyak peraturan perundang- undangan yang ada di Indonesia untuk memberikan perlindungan hukum terhadap anak yang bekerja ada hal- hal lain yang harus lebih ditekankan karena pada kenyataanya pelaksanaan peraturan perundang- undangan masih banyak kekurangan. Untuk mengatasi masalah pekerja anak ini ada tiga pendekatan yang dapat dilakukan yaitu penghapusan (abolition), perlindungan (protection), dan pemberdayaan (empowerment) dengan memperhatikan tiga asas yaitu asas pencegahan, asas penerapan secara efektif dan asas kerjasama nasional. Dalam hal ini terdapat lima langkah yang mnejadi prioritas yaitu pertama, mengubah persepsi msyarakat terhadap pekerja anak, kedua, melakukan advokasi secara bertahap untuk mengeliminasi pekerja anak, ketiga, mengundangkan dan melaksanakan peraturan perundang- undangan bagi perlindungan pekerja anak yang berwawasan gender analisis, keempat, mengupayakan perlindungan hukum dan menyediakan pelayanan yang memadai bagi anak- anak, dan kelima memastikan agar anak- anak yang bekerja memperoleh pendidikan dasar 9 tahun. Dari semua bentuk perlindungan terhadap pekerja anak berwawasan gender tersebut secara umum dapat dibagi menjadi perlindungan langsung dan tidak langsung.
\end{abstract}

Kata Kunci: Perlindungan Hukum, Pekerja Anak, Gender

\section{Abstract}

This research discuss the problems of the legal protection of children workers in Indonesia are still not yet implemented properly even though it has many instruments of law that are pay attention on the rights of the children. From the results of this research shown that the protection of children had been integrated in national law contained in KUHPerdata, KUHPidana, and a number of laws. As an attempt to enforce legal protection for children workers there are at least five factors which should be strengthened, namely legal factors, law 
enforcement factor, means and facilities of law factor, Community law factor, and cultural law factor.

Form of legal protection of children workers in Indonesia with gender perspective in addition that have already exist many laws that are provide legal protection of childrenren workers there are other things that should be more emphasized because in fact the implementation of laws are still many weaknesses. To solve the problem of children workers there are three approaches that can be done: the deletion (abolition), protection (protection), and enablement (empowerment) with give attention to three basic basic prevention, i.e. the application of the principle of cooperation and effective nationwide. In this case there are five steps that become priorities: first, changing public perception against children workers, second, advocate gradually to eliminate children workers, third, instituted and carried out laws for the protection of children workers with gender analysis Fourth, seek legal protection and providing adequate services to children, and the fifth to ensure that children workers acquire basic education 9 years. Of all the forms of protection against children workers with gender analysis in General can be divided into direct and indirect protection.

Key Words: Legal Protection, Children Workers, Gender Analysis

\section{A. Pendahuluan}

Perhatian terhadap anak sudah lama ada sejalan dengan peradaban manusia itu sendiri, yang dari ke hari semakin berkembang. Anak adalah putra kehidupan, masa depan bangsa dan negara. Indonesia merupakan salah satu negara yang meratifikasi konvensi Perserikatan Bangsa-Bangsa (PBB) tentang Hak-Hak Anak melalui Kepres No. 36 tanggal 25 Agustus 1990. Dengan diratifikasinya konvensi tersebut, berarti secara hukum negara berkewajiban melindungi dan memenuhi hak-hak Anak, baik hak sipil, politik, sosial, budaya dan ekonomi.

Akan tetapi ada kenyatannya negara masih belum mampu memenuhi kewajibannya untuk melindungi hak-hak anak. Salah satu permasalahan yang masih terjadi adalah keberadaan pekerja anak. Bukan hanya melanggar hak-hak anak, bekerja juga membawa dampak buruk bagi anak-anak, baik secara fisik maupun psikis. Lebih jauh, bekerja dikhawatirkan akan mengganggu masa depan anak-anak untuk mendapat kehidupan kehidupan yang lebih baik.

Sekalipun banyak kekhawatiran yang muncul, permasalahan pekerja anak di indonesia ternyata tidak dapat disikapi dengan pilihan boleh atau tidak. Kenyataan menunjukkan bahwa keluarga miskin sangat membutuhkan pekerjaan bagi anak-anaknya, baik untuk membantu perekonomian keluarga, maupun melangsungkan hidupnya sendiri. 
Menurut Panji Putranto, Idealnya anak-anak memang tidak perlu bekerja, akan tetapi ketika keadaan sosial-ekonomi memaksa mereka bekerja, maka menghapus pekerja anak merupakan tindakan yang tidak logis. ${ }^{1}$

KHA, dalam pendahuluannya yang dicetuskan oleh PBB (United Nations Convention on the Rights of the Child/CRC) menyatakan bahwa anak karena ketidakmatangan fisik dan mentalnya, membutuhkan perlindungan dan perawatan khusus, termasuk perlindungan hukum yang layak, sebelum dan sesudah kelahiran. Dalam hubungannya dengan orang dewasa atau orang tua, anak-anak pada umumnya memiliki posisi tersubordinasi. Ketergantungan anak-anak pada orang tua pada khususnya dan orang dewasa pada umumnya yang secara tradisional merupakan "pengasuh" mereka menyebabkannya mempunyai otoritas terhadap anak-anak. Hal ini mengondisikan anak-anak sebagai target kekerasan dan salah perlakuan. $^{2}$

Secara umum upaya perlindungan anak khususnya pekerja anak merupakan upaya perlindungan terhadap hak asasi manusia. Instrumen hukum yang merupakan landasan bagi upaya perlindungan hak asasi manusia adalah The Declaration Universal of Human Rights 1948 atau Deklarasi Universal Hak-Hak Asasi Manusia (DUHAM). Deklarasi ini merupakan perjanjian payung hak asasi manusia yang merupakan peraturan utama yang menatur perlindungan hak sasi manusia. Secara khusus lagi masalah perlindungan anak diatur dalam The Convention On The Rights of he child atau konvensi hak anak.

Di Jawa Timur, jumlah pekerja anak yang berusia 10-14 tahun sebanyak 301.036 anak-88, 20\% berada di desa sedang selebihnya, 11,80\% berada di kota $71,44 \%$ di antaranya bekerja di sektor pertanian dan urutan kedua di sektor industri kecil yakni 11,30\%. Ini dapat kita maklumi karena bekerja pada kedua sektor tersebut tidak membutuhkan persyaratan yang ketat dan mekanisme rekrutmen yang sangat longgar. Jika dikaitkan antara tingkat pendidikan dengan sektor pekerjaan yang ditekuni anak dapat diketahui bahwa $50,10 \%$ yang bekerja di sektor pertanian tidak/belum tamat SD, 47,34\% tamat SD dan hanya 0,58\% yang tamat SLTP. Sedangkan yang bekerja di sektor industri kecil 27, 42\% tidak/belum tamat SD, 67, 69\% tamat SD dan hanya 2,91\% yang tamat SLTP. ${ }^{3}$

Isu pekerja anak umumnya dikaitkan dengan permasalahan pendidikan dasar, karena pekerja anak menjadi rawan putus sekolah, disamping permasalahan kesehatan sebagai

\footnotetext{
${ }^{1}$ Hardius Usman dan Nachrowi D Nachrowi, Pekerja Anak di Indonesia, PT Gramedia Widiasarana, Jakarta, 2004, hal 2.

${ }^{2}$ Putranto. (11 Januari 1992). Perbincangan seputar anak. Diambil pada tanggal 7 September 2009, dari http://www.S.S.net.com/humana/bab2

${ }^{3}$ Survey Kesejahteraan Nasional / Susenas. (2004). Jakarta: Biro Pusat Statistik (BPS).
} 
dampak kegiatan bekerja yang buruk. Hal ini berhubungan dengan hak anak dalam proses tumbuh kembang, khususnya hak mengenyam pendidikan dan akses kesehatan secara optimal. Pada hakekatnya anak tidak boleh bekerja karena waktu mereka selayaknya dimanfaatkan untuk belajar, bemain, bergembira, berada dalam suasana damai dan mendapatkan kesempatan serta fasilitas untuk mencapai cita-cita sesuai dengan perkembangan fisik, psikologis, intelektual dan sosialnya. Pasal 68 UU No. 13 Tahun 2003 tentang ketenagakerjaan menyatakan bahwa menyatakan bahwa pengusaha dilarang mempekerjakan anak.

Pada kenyataannya anak di bawah umur yang terlibat aktif dalam kegiatan ekonomi, salah satu alasannya adalah tekanan ekonomi yang di alami orang tua atau faktor sosial budaya penduduk setempat. Berdasarkan pemaparan latar belakang masalah di atas, penulis hendak melakukan penelitian dengan judul Refleksi Perlindungan Hukum Terhadap Pekerja Anak Berwawasan Gender.

B. Metode Penelitian

Penelitian ini menggunakan jenis penelitian hukum normatif berupa penelitian kepustakaan yang menggunakan 3 bahan hukum yaitu bahan hukum primer, bahan hukum sekunder dan bahan hukum tersier. Penelitian hukum ini menitikberatkan pada studi kepustakaan yang berarti akan lebih banyak menelaah dan mengkaji aturan-aturan hukum yang ada dan berlaku. Adapun isu hukum yang dikaji dalam penelitian normatif ini adalah bagaimana refleksi perlindungan hukum terhadap pekerja anak berwawasan gender dan bagaimana bentuk perlindungan hukum terhadap pekerja anak di Indonesia berwawasan gender.

Penelitian ini menggunakan metode pendekatan perundang-undangan (statute approach) dan pendekatan konseptual (conceptual approach). Pendekatan perundangundangan (statute approach) yaitu penelitian terhadap produk-produk hukum. ${ }^{4}$ Produk hukum yang dimaksud UUD NRI 1945, Undang-Undang No. 39 Tahun 1999 tentang Hak Asasi Manusia, Undang-UU No. 13 Tahun 2013 tentang Ketenagakerjaan, Undang Nomor 23 Tahun 2002 Tentang Perlindungan Anak jo Undang-Undang Nomor 35 Tahun 2014 Tentang Perubahan Undang-Undang Nomor 23 Tahun 2002 Tentang Perlindungan Anak. Aturan ini digunakan untuk menelaah bagaimana refleksi perlindungan hukum terhadap pekerja anak berwawasan gender.

\footnotetext{
${ }^{4}$ Peter Mahmud Marzuki, Op Cit., hlm. 138.
} 
Pendekatan konseptual (conceptual approach) beranjak dari pandangan-pandangan dan doktrin-doktrin yang berkembang di dalam ilmu hukum, untuk menemukan ide-ide yang melahirkan konsep-konsep hukum, dan asas-asas hukum yang relevan dengan isu hukum. ${ }^{5}$ Pendekatan konseptual (conceptual approach) merupakan suatu pendekatan yang digunakan untuk memperoleh kejelasan dan pembenaran ilmiah berdasarkan konsep-konsep hukum yang bersumber dari prinsip-prinsip hukum. ${ }^{6}$ Konsep hukum yang dibangun dalam penelitian ini adalah bagaimana bentuk perlindungan hukum terhadap pekerja anak di Indonesia berwawasan gender.

Bahan hukum primer yang digunakan dalam penelitinan ini adalah UUD NRI 1945, Undang-Undang No. 39 Tahun 1999 tentang Hak Asasi Manusia, Undang-UU No. 13 Tahun 20013 tentang Ketenagakerjaan, Undang Nomor 23 Tahun 2002 Tentang Perlindungan Anak jo Undang-Undang Nomor 35 Tahun 2014 Tentang Perubahan Undang-Undang Nomor 23 Tahun 2002 Tentang Perlindungan Anak.

Bahan hukum sekunder berupa publikasi tentang hukum yang bukan merupakan dokumen-dokumen resmi. Publikasi tentang hukum ini meliputi buku-buku teks, kamuskamus hukum, jurnal-jurnal hukum, dan komentar-komentar atas putusan pengadiilan. ${ }^{7}$

Bahan hukum tersier adalah bahan-bahan yang memberikan petunjuk atau penjelasan bermakna terhadap bahan hukum primer dan bahan hukum sekunder, seperti kamus hukum dan eksiklopedi. Kamus hukum yang digunakan dalam penelitian ini adalah Black's Law Dictionary.

Teknik pengumpulan bahan hukum dilakukan dengan cara studi kepustakaan (Library Research), yaitu dengan melakukan penelusuran terhadap bahan-bahan hukum yang ada relevansinya dengan pokok permasalahan yang menjadi kajian dalam penelitian ini. Setelah semua bahan hukum dikumpulkan, Langkah selanjutnya adalah pemetaan bahan-bahan hukum tersebut sesuai dengan pokok permasalahan. Untuk mempermudah pemetaan tersebut dilakukan dengan cara komputerisasi dengan memasukkan bahan-bahan hukum tersebut ke dalam file/folder sesuai dengan item-item pembahasan.

\section{Pembahasan}

\section{Pengertian Anak dan Pekerja Anak}

\footnotetext{
${ }^{5}$ Ibid, 95 .

${ }^{6}$ Ibid, hlm. 138.

${ }^{7}$ Ibid.
} 
Menurut W.J.S Poerdaminta memberikan pengertian anak sebagai manusia yang kecil. $^{8}$ R.A. Koesnoen memberikan pengertian anak sebagai manusia muda, muda dalam umur, muda dalam jiwa dan pengalaman hidup, karenanya mudah terpengaruh keadaan sekitarnya. ${ }^{9}$

Menurut ketentuan pasal 330 KUHPerdata memberikan pegertian anak atau orang yang belum dewasa adalah sebagai berikut:

"Belum dewasa adalah seseorang yang belum mencapai umur genap 21 tahun dan tidak lebih dahulu kawin. Apabila seseorang yang belum mencapai umur 21 tahun telah kawin, dan perkawinan itu dibubarkan sebelum umurnya genap 21 tahun maka ia tidak kembali lagi ke kedudukan belum dewasa.

Menurut Undang-Undang No.1 Tahun 1974 Tentang Perkwinan, tidak mengatur tentang pengertian anak, namun di dalam pasal 7, disebutkan bahwa "perkawinan hanya diizinkan jika pihak pria sudah mencapai umur 19 (sembilan belas) tahun dan pihak wanita sudah mencapai umur 16 (enam belas) tahun. Dari ketentuan UU No.1 Tahun 1974 dapat disimpulkan bahwa anak adalah seseorang di bawah umur 19 tahun bagi seorang laki-laki dan di bawah umur 16 tahun bagi seorang perempuan.

Pasal 1 Butir 1 UU No.23 Tahun 2002 tentang Perlindungan Anak, anak adalah seseorang yang belum berusia 18 (delapan belas) tahun, termasuk anak yang masih dalam kandungan. Sedangkan menurut Pasal 1 angka 26 UU No.13 Tahun 2003 tentang Ketenagakerjaan, anak adalah setiap orang yang berumur dibawah 18 (delapan belas) tahun.

Dengan demikian maka pengertian anak atau juvenile pada umumnya adalah seorang yang masih di bawah umur tertentu, yang belum dewasa dan belum pernah kawin. Pada beberapa peraturan perundang-undangan di indonesia mengenai batas umur kedewasaan seseorang berbeda-beda. Perbedaan tersebut tergantung dari sudut manakah dilihat dan ditafsirkan, apakah dari sudut pandang perkawinan, dari sudut pandang kesejahteraan anak, dan dari sudut andang lainnya. Hal ini tentu ada pertimbangan aspek psikologis, yang menyangkut kematangan jiwa seseorang. Batas umur minimum ini berhubungan erat dengan soal, pada umur berapakah pembuat atau pelaku tindak pidana dapat dihadapkan ke pengadilan dan dapat dipertanggungjawabkan atas tindak pidana yang dilakukannya. Sedangkan batas umur maksimum dalam hukum pidana untuk menetapkan siapa saja yang

\footnotetext{
${ }^{8}$ WJS poerdaminta, Kamus umum Bahasa indonesia, Batavia, Balai Pustaka, 1976. Hal 753

${ }^{9}$ R.A. Koesnoen, Susunan Pidana Dalam Negara Indonesia, Sumur, Bandung, 1964. Hal 120
} 
sampai batas umur ini diberikan kedudukan anak atau juvenile, sehingga harus diberi perlakuan hukum secara khusus. ${ }^{10}$

Menurut ketentuan pasal 1 angka 3 UU No.13 Tahun 2003 tentang ketenagakerjaan, menjelaskan bawa Pekerja/buruh adalah setiap orang yang bekerja dengan menerima upah atau imbalan dalam bentuk lain. Jadi disini disebutkan bahwa pekerja adalah semua orang yang bekerja dalam bentuk apapun dan dia menerima upah atau imbalan dalam bentuk apapun. Jadi pekerja anak adalah setiap anak yang sehari-harinya bekerja untuk memenuhi kehidupan dirinya dan keluarganya.

\section{Hak Dan Kewajiban Pekerja/Buruh Dan Pengusaha/Pemberi Kerja}

a. Hak dan kewajiban Pekerja/buruh

Menurut Pasal 1 angka 14 Undang-Undang No 13 Tahun 2003, perjanjian kerja adalah perjanjian antara pekerja/buruh dengan pengusaha atau pemberi kerja yang memuat syarat-syarat kerja, hak dan kewajiban para pihak.

Bentuk perjanjian kerja adalah bebas, artinya perjanjian kerja tersebut dapat dibuat secara tertulis atau lisan (Pasal 51 ayat (1) Undang-Undang No 13 Tahun 2003). Pada prinsipnya perjanjian kerja yang dibuat secara tertulis lebih menjamin kepastian hukum. Namun melihat kondisi masyarakat yang beragam dimungkinkan perjanjian kerja secara lisan asalkan perjanjian tersebut disepakti kedua belah pihak yaitu pekerja/buruh dengan pengusaha.

Berakhirnya perjanjian kerja dapat disebabkan oleh beberapa hal sebagaimana disebutkan dalam Pasal 61 ayat (1) Undang-Undang No 13 Tahun 2003 yaitu :

1) Pekerja meninggal dunia;

2) Berakhirnya jangka waktu perjanjian;

3) Adanya persetujuan pengadilan dan atau putusan atau penetapan lembaga penyelesaian perselisihan perburuhan yang telah mempunyai kekuatan hukum tetap;

4) Adanya keadaan atau kejadian tertentu yang dicantumkan dalam perjanjian kerja, peraturan perusahaan, atau perjanjian kerja bersama yang dapat menyebabkan berakhirnya hubungan kerja.

Dengan terjadinya perjanjian kerja, akan menimbulkan hubungan kerja antara pekerja/buruh dan pengusaha yang berisikan hak dan kewajiban bagi masing-masing pihak. Hak dari pihak yang satu merupakan kewajiban bagi pihak lainnya, sebaliknya kewajiban pihak yang satu merupakan hak bagi pihak lainnya.

1. Hak-Hak Pekerja/buruh

a. Imbalan kerja

${ }^{10}$ Made Sadhi Astuti, Hukum Pidana Anak Dan Perlindungan Anak, UM Press, Malang, 2003, hal 9 
b. Fasilitas berbagai tunjangan, bantuan yang menurut perjanjian akan diberikan oleh pihak pengusaha

c. Mengembangkan kompetensi kerja sesuai dengan bakat, minat dan kemampuannya melalui pelatihan kerja.

d. Mendapatkan perlindungan atas keselamatan, kesehatan, kesusilaan, pemeliharaan moril kerja serta perlakuan yang sesuai dengan harkat dan martabat manusia dan moral agama.

e. Mendirikan dan menjadi anggota serikat pekerja/buruh.

2. Kewajiban pekerja/ buruh

a. Melakukan pekerjaan

b. Mematuhi perintah dari pengusaha

c. Membayar denda atas kelalaiannya.

b. Hak Dan Kewajiban Pengusaha/Pemberi Kerja

Menurut Pasal 1 angka 5 Undang-Undang No. 13 Tahun 2003, yang dimaksud pengusaha adalah :

a. Orang perseorangan, persekutuan, atau badan hukum yang menjalankan suatu perusahaan milik sendiri;

b. Orang perseorangan, pesekutuan, atau badan hukum yang secara berdiri sendiri menjalankan perusahaan bukan miliknya ;

c. Orang perseorangan, persekutuan, atau badan hukum yang berada di Indonesia mewakili perusahaan sebagaimana dimaksud dalam huruf a dan b yang berkedudukan di luar wilayah Indonesia.

\section{Hak seorang Pengusaha/Pemberi Kerja}

Pengusaha berhak membuat peraturan perusahaan. Pembuatan peraturan perusahaan ini berdasarkan Pasal 1 bagian a Peraturan Menteri Nomor 02/MEN/1978 tentang Peraturan Perusahaan dan Perundingan Pembuatan Perjanjian Perburuhan yang menyatakan bahwa : "Peraturan perusahaan adalah suatu peraturan yang dibuat secara tertulis yang memuat ketentuan tentang syarat-syarat kerja serta tata tertib perusahaan".

Sedangkan menurut Pasal 1 angka 20 Undang-Undang No. 13 Tahun 2003, yang menyatakan bahwa : "Peraturan perusahaan adalah peraturan yang dibuat secara tertulis oleh pengusaha yang memuat syarat-syarat kerja dan tata tertib perusahaan”.

Jadi peraturan perusahaan merupakan peraturan yang dibuat secara tertulis oleh pengusaha yang berisi syarat-syarat kerja dan tata tertib perusahaan. Peraturan perusahaan hanya dibuat 
secara sepihak oleh pengusaha yang mempunyai pekerja/buruh lebih dari 25 (dua puluh lima) orang. Dalam pembuatan peraturan perusahaan pekerja/buruh tidak ikut serta menentuan isinya, oleh karena itu ada yang menyatakan bahwa peraturan perusahaan adalah peraturan yang berisi terpisah dari perjanjian kerja.

\section{Kewajiban Pengusaha/Pemberi Kerja}

a. Membayar upah

b. Memberikan Surat Keterangan

c. Memberikan waktu istirahat mingguan dan hari libur

\section{Konsep Dasar Perlindungan Hukum Terhadap Anak.}

\section{Prinsip Dasar Perlindungan}

Perlindungan hukum menurut Satjipto Raharjo yaitu dimana hukum melindungi kepentingan seseorang dengan cara menempatkan suartu kekuasaan yang dilakukan secara terukur (tertentu dan dalamnya) untuk bertindak dalam rangka kepentingan tersebut. ${ }^{11}$

Philipus M.Hadjon mempunyai pemikiran lain mengenai perlindungan hukum. Menurutnya perlindungan hukum adalah perlindungan harkat dan martabat serta pengakuan terhadap hak asasi manusi yang dimiliki oleh subyek hukum dalam negara hukum berdasarkan ketentuan hukum dari kesewenang-wenangan. Perlindungan hukum dikategorikan menjadi dua, yaitu: ${ }^{12}$

1. Perlindungan Hukum Preventif.

Perlindungan hukum yang memberikan kesempatan rakyat untuk mengajukan keberatan (inspraak) atau pendapatnya sebelum suatu keputusan pemerintah mendapat bentuk definitif.

\section{Perlindungan Hukum Refresif}

Perlindungan hukum refresif bertujuan untuk menyelesaikan suatu sengketa dengan cara penetapan sanksi hukum terhadap pelanggaran hukum yang merugikan kepentingan hukum atau kepentingan pribadi orang lain, baik melaui mekanisme pengadilan maupun di luar pengadilan.

\footnotetext{
${ }^{11}$ Satjipto Raharjo, Ilmu Hukum, Citra Aditya Bakti, Bandung, 1991, hal 53

12 Philipus M.Hadjon, Pengantar hukum administrasi indonesia, Gajah Mada University press, Yogyakarta, 2002, hal 37.
} 
Menurut Soerjono Dirjosisworo, ada berbagai upaya perlindungan bagi masyarakat secara umum, meliputi: ${ }^{13}$

a. Perlindungan individu dari gangguan orang lain ata kelompok dalam pergaulan hidup yang karena berbagai faktor berbuat merugikan.

b. Perlindungan individu tersangka atas terdakwa dalam suatu perkara pidana kemungkinan timbulnya tindakan kesewenangan oknum aparat penegak hukum.

c. Perlindungan masyarakat atas kemungkinan berbuat atau tidak berbuat dari warga masyarakat.

Berbicara tentang perlindungan hukum, maka hal tersebut merupakan bentuk konsekuensi dari suatu bentuk negara hukum. "Negara indonesia berdasar atas hukum (rechstaat) dan tidak berdasar asas kekuasaan belaka (machstaat)". Pemerintah berdasarkan atas sistem konstitusi tidak bersifat absolutisme. ${ }^{14}$

Berdasakan hal tersebut dapatlah dinyatakan bahwa sistem negara hukum merupakan merupakan piliha negara kita. Yang pada selanjutnya hukum mengalami perkembangan, dimana perkembangan hukum mencakup pengembangan perangkat/ketentuan-ketentuan hukum, pemantapan penegakan hukum serta peningkatan kesadaan hukum, yang ditujukan untuk memantapkan perwujudan negara hukum, tahap demi tahap. ${ }^{15}$

Pada perkembangan selanjutnya hukum yang diharapkan masyarakat mampu memenuhi tuntutan yang ada di masyarakat, sehingga konsepsi pembangunan pun dapat mempengaruhi hukum. Hukum dalam pembangunan mempunyai empat fungsi, yaitu:

1. Hukum sebagai pemelihara ketertiban

2. Hukum sebagai srana pembangunan

3. Hukum sebagai sarana penegak keadilan

4. Hukum sebagai sarana pendidikan masyarakat.

\section{Perlindungan Hukum Terhadap Anak}

Menurut pasal 1 angka 4 UU No.23 Tahun 2004 tentang Penghapusan Kekerasan Dalam Rumah Tangga (PKDRT), Perlindungan adalah segala upaya yang ditujukan untuk memberikan rasa aman kepada korban yang dilakukan oleh pihak keluarga, advokat, lembaga sosial, kepolisian, kejaksaan, pengadilan, atau pihak lainnya baik sementara maupun berdasarkan penetapan pengadilan.

\footnotetext{
${ }^{13}$ Philipus M.Hadjon, Perlindungan Hukum bagi rakyat Indonesia, Bina Ilmu, Surabaya, 1987, hal 2

${ }^{14}$ Sudjono, Saukarto, Marmo, Penegakan hukum dinegara pancasila, Garuda Metropolis perss, Jakarta, 1997, hal 16

${ }^{15}$ Ibid hal 18
} 
UU No.23 Tahun 2002 tentang Perlindungan Anak, pasal 1 angka 2 menjelaskan bahwa perlindungan anak adalah adalah segala kegiatan untuk menjamin dan melindungi anak dan hak-haknya agar dapat hidup, tumbuh, berkembang, dan berpartisipasi, secara optimal sesuai dengan harkat dan martabat kemanusiaan, serta mendapat perlindungan dari kekerasan dan diskriminasi.

Pengertian Perlindungan anak menurut para ahli:

a. Menurut Gosita, hukum perlindungan anak adalah hukum tertulis maupun hukum tidak tertulis yang menjamin anak benar-benar dapat melaksanakan hak dan kewajibannya. ${ }^{16}$

b. Menurut J.F. Doek dan H.M.A. Drewes memberikan pengertian perlidungan anak dalam dua pengertian, yakni:

1. Dalam arti luas, yaitu segala aturan hidup yang memberi perlindungan kepada mereka yang belum dewasa dan memberi kemungkinan kepada mereka untuk berkembang

2. Dalam arti sempit, yaitu perlindungan hukum yang terdapat dalam ketentuan hukum perdata, ketentuan hukum pidana dan ketentuan hukum acara. ${ }^{17}$

c. Soemitro menjelaskan secara garis besar, perlindungan anak dibedakan ke dalam dua sifat, yakni:

1. Perlindungan yang bersifat yuridis adalah menyangkut semua aturan hkum yang mempunyai pengaruh atau dampak langsung bagi kehidupan seorang anak, dalam arti semua aturan hukum yang mengaur kehidupan anak, meliputi perlindungan dalam bidang hukum publik dan dalam bidang hukum keperdataan

2. Perlindungan yang bersifat non yuridis meliputi bidanng sosial, bidang kesehatan, dan bidang pendidikan. ${ }^{18}$

\section{Ketentuan hukum positif tentang pekerja anak}

Menurut pasal 1 Permennaker RI No.10/Men/1987 tentang perlindungan anak yang terpaksa bekerja di definisikan sebagai berikut:

"Anak yang berumur di bawah 14 tahun karena alasan sosial ekonomi terpaksa bekerja untuk menambah penghasilan baik untuk keluarga maupun memperoleh penghasilan untuk dirinya sendiri", Sedangkan ayat dua mensyaratkan adanya izin dari orang tua/wali bagi anak yang terpaksa bekerja

Instruktur Hukum Internasional yang mengatur anak sebagai pekerja adalah Konvensi ILO No.138 Tahun 1973 (dirativikasi melalui UU No.20 Tahun 1999) yang

\footnotetext{
${ }^{16}$ Arif Gosita, Masalah korban kejahatan, Akademika Pressindo, Jakarta, 1983, hal 53

${ }^{17}$ Soemitro, Aspek Hukum Perlindungan Anak, Bumi Aksara, Jakarta, 1990, hal 15-16

${ }^{18}$ Ibid hal 13
} 
menjelaskan bahwa anak sebagai pekerja adalah anak yang berusia kurang dari 15 tahun untuk jenis kegiatan pekerjaan dalam wilayah suatu negara dan pada alat pengangkutan yang ada dalam wilayahnya (pasal 2 ayat 1), dan konvensi ILO No.182 Tahun 1999 (dirativikasi melalui UU No. 1 tahun 2000) menyatakan bahwa anak sebagai pekerja adalah pekerja yang berusia di bawah 18 tahun (pasal 1,2,3 ILO)

Menurut Surat Edaran Menteri Tenaga Kerja RI No.SE-12/M/BW/1997 adalah untuk perlindungan pekerja anak, kerja bagi anak sepanjang tidak mengganggu fisik, mental, sosial seperti kegiatan yang dapat meningkatkan perkembangan kreativitas membina kedisiplinan dan menumbuhkan kemandirian perlu dibiasakan. Untuk dapat terjaminnya perkembangan anak yang wajar, perlu ditetapkan industri dan pekerjaan yang dilarang yaitu:
a. Pertambangan, baik galian dipermukaan maupun dibawah tanah
b. Metarlurgi
c. Pelepasan dan peleburan logam
d. Marinim khususnya mekanik dan juru api
e. Jermal
f. Usaha-usaha kedalam air
g. Mesin pengerak-penggerak, dalah hal ini mendekati, mereparasi
h. Mengoperasikan dan merawat gergajo berputar
i. Mengangkat dan mengangkut beban yang memina dan banyak energi dan merubah postur tubuh
j. Bekerja dengan pesawat angkasa dan angkut
k. Konstruksi, reparasi dan menmbah bangunan baik jalan, gudang maupun irigasi
1. Usaha perkebunan, kehutanan, pengolahan kayu dan pertanian
m. Rumah potong dan pengolahan daging
n. Penyamakan kulit
o. Perusahaan tekstil
p. Perusahaan jasa hiburan
q. Produksi dan penjualan minuman keras
r. Produksi dan pengedar bahan pornografi
s. Transportasi umum baik baik bagi orang maupun barang
t. Industri barang peledak baik yang membuat
u. Industri yang dalam prosesnya menimbulkan uap, asap, debu, gas dan bahan polutan lainnya dalam udara
v. Usaha-uasaha dimana terdapat bahan radioaktif dan atau irigasi mugion
w. Pekerjaan dimana terdapat penampungan bahan patogen seperti bekerja di rmah sakit
x. Pekerjaan yang menggunakan peralatan yang dialiri arus listrik.

Hak anak sebagai bagian Hak Asasi Manusia telah dirumuskan dalam pasal 52 ayat (2) UU No. 39 Tahun 1999, dalam hal ini perlindungan terhadap hak-hak anak tidak hanya menjadi tanggung jawab negara, melainkan menjadi tanggung jawab orang tua, keluarga, dan masyarakat. Secara umum UU hak asasi manusia memberikan perlindungan terhadap anak sebagai pekerja melalui rumusan pasal 64. 
UU No.4 Tahun 1979 Tentang Kesejahteraan Anak tidak secara langsung mengatur masalah perlindungan anak terhadap eksploitasi sebagai pekerja, tetapi melihat permasalahan anak sebagai pekerja dalam kerangka perlindungan anak, maka akan ditemukan bahwa eksploitasi anak sebagai pekerja sebagai suatu hal yang bertentangan dengan UU ini.

Pasal 2 UU No.23 Tahun 2002 Tentang Perlindungan Anak menyatakan bahwa Penyelenggaraan perlindungan anak berasaskan Pancasila dan berlandaskan Undang-Undang Dasar Negara Republik Indonesia Tahun 1945 serta prinsip-prinsip dasar Konvensi Hak-Hak Anak meliputi: (1)Non diskriminasi; (2) kepentingan yang terbaik bagi anak; (3) hak untuk hidup, kelangsungan hidup, dan perkembangan; dan (4) penghargaan terhadap pendapat anak.

Pasal 59 UU No.23 Tahun 2002, berbunyi Pemerintah dan lembaga negara lainnya berkewajiban dan bertanggung jawab untuk memberikan perlindungan khusus kepada anak dalam situasi darurat, anak yang berhadapan dengan hukum, anak dari kelompok minoritas dan terisolasi, anak tereksploitasi secara ekonomi dan/atau seksual, anak yang diperdagangkan, anak yang menjadi korban penyalahgunaan narkotika, alkohol, psikotropika, dan zat adiktif lainnya (napza), anak korban penculikan, penjualan dan perdagangan, anak korban kekerasan baik fisik dan/atau mental, anak yang menyandang cacat, dan anak korban perlakuan salah dan penelantaran.

Sedangkan pasal Pasal 66 berbunyi: (1) Perlindungan khusus bagi anak yang dieksploitasi secara ekonomi dan/atau seksual sebagaimana dimaksud dalam Pasal 59 merupakan kewajiban dan tanggung jawab pemerintah dan masyarakat. Ayat (2) berbunyi Perlindungan khusus bagi anak yang dieksploitasi sebagaimana dimaksud dalam ayat (1) dilakukan melalui : a. penyebarluasan dan/atau sosialisasi ketentuan peraturan perundangundangan yang berkaitan dengan perlindungan anak yang dieksploitasi secara ekonomi dan/atau seksual; b. pemantauan, pelaporan, dan pemberian sanksi; dan c. pelibatan berbagai instansi pemerintah, perusahaan, serikat pekerja, lembaga swadaya masyarakat, dan masyarakat dalam penghapusan eksploitasi terhadap anak secara ekonomi dan/atau seksual. Sedangkan ayat (3) menyatakan Setiap orang dilarang menempatkan, membiarkan, melakukan, menyuruh melakukan, atau turut serta melakukan eksploitasi terhadap anak sebagaimana dimaksud dalam ayat (1).

Pasal 68 UU No.13 Tahun 2003 Tentang Ketenagakerjaan berbunyi Pengusaha dilarang mempekerjakan anak. Tetapi di pasal 69 ayat (1) menyatakan Ketentuan sebagaimana dimaksud dalam Pasal 68 dapat dikecualikan bagi anak yang berumur antara 13 
(tiga belas) tahun sampai dengan 15 (lima belas) tahun untuk melakukan pekerjaan ringan sepanjang tidak mengganggu perkembangan dan kesehatan fisik, mental, dan sosial.

Ayat (2) menyatakan bahwa Pengusaha yang mempekerjakan anak pada pekerjaan ringan sebagaimana dimaksud dalam ayat (1) harus memenuhi persyaratan :

a. Izin tertulis dari orang tua atau wali;

b. Perjanjian kerja antara pengusaha dengan orang tua atau wali;

c. Waktu kerja maksimum 3 (tiga) jam;

d. Dilakukan pada siang hari dan tidak mengganggu waktu sekolah;

e. Keselamatan dan kesehatan kerja;

f. Adanya hubungan kerja yang jelas; dan

g. Menerima upah sesuai dengan ketentuan yang berlaku.

Sedangkan ayat (3) berbunyi Ketentuan sebagaimana dimaksud dalam ayat (2) huruf a, b, f, dan g dikecualikan bagi anak yang bekerja pada usaha keluarganya.

Mengenai Eksploitasi pekerja anak, pasal 74 UU No.13 Tahun 2003 berbunyi: (1) Siapapun dilarang mempekerjakan dan melibatkan anak pada pekerjaan-pekerjaan yang terburuk. (2) Pekerjaan-pekerjaan yang terburuk yang dimaksud dalam ayat (1) meliputi : a. segala pekerjaan dalam bentuk perbudakan atau sejenisnya; b. segala pekerjaan yang memanfaatkan, menyediakan, atau menawarkan anak untuk pelacuran, produksi pornografi, pertunjukan porno, atau perjudian; c. segala pekerjaan yang memanfaatkan, menyediakan, atau melibatkan anak untuk produksi dan perdagangan minuman keras, narkotika, psikotropika, dan zat adiktif lainnya; dan/atau d. semua pekerjaan yang membahayakan kesehatan, keselamatan, atau moral anak.

Sedangkan pasal 75 UU ini pemerintah Pemerintah berkewajiban melakukan upaya penanggulangan anak yang bekerja di luar hubungan kerja. Jadi disini ditegaskan bahwa pemerintah juga berkewajiban memberikan perlindungan terhadap anak sebagai pekerja di luar hubungan kerja.

Berdasarkan uraian diatas tentang bagaimana perlindungan secara hukum dari pekerja anak terutama pekerja anak di sektor nelayan maka di tarik benang merah untuk permasalahan perlindungan pekerja anak dalam tatanan hukum indonesia telah terdapat instrumen hukum perlindungan anak, diantaranya adalah konvensi PBB tentang hak-hak anak, UU No.13 Tahun 2003 serta ratifikasi konvensi ILO 138 dan 182. 


\section{Refleksi Perlindungan Hukum Terhadap Pekerja Anak Berwawasan Gender}

Perlindungan terhadap anak sebenarnya telah terintegrasi dalam hukum nasional yang terkandung dalam KUHPerdata, KUHPidana, dan sejumlah peraturan perundang- undangan tentang perlindungan anak. Secara internasional, sejak tahun 1989 masyarakat dunia telah mempunyai instrumen hukum, yakni dengan adanya Konvensi Hak Asasi Anak (Un's Convention on the Rights of the Child). KHA mendeskripsikan hak- hak anak secara detail, menyeluruh dan maju. Karena KHA memposisikan anak sebagai dirinya sendiri dan anak sebagai segmen manusia yang harus dibantu perjuangan bersama-sama orang dewasa.

Pada hakekatnya anak tidak boleh bekerja, sudah sewajarnya bahwa waktu mereka dimanfaatkan untuk nelajar, bermain, bergembira, berada dalam suasana damai, mendapatkan kesempatan dan fasilitas untuk mencapai cita- citanya sesuai dengan perkembangan fisik, psikologik, intelektual, dan sosialnya. Namun pada kenyataannya banyak anak- anak dibawah usia 18 tahun yang telah terlibat aktif dalam kegiatan ekonomi, menjadi pekerja anak dalam berbagai sektor dengan alasan ekonomi keluarga ataupun faktor lainnya. Pada kenyataanya isu pekerja anak bukan sekedar isu anak menjalankan pekerjaan dengan memperoleh upah, akan tetapi lekat sekali dengan persoalan eksploitasi, pekerjaan berbahaya, terhambatnya akses pendidikan dan menghambat perkembangan fisik, psikis dan sosial anak. Bahkan dalam kasus dan bentuk tertentu pekerja anak telah masuk sebagai kualifikasi anak-anak yang bekerja pasa situasi yang paling tidak bisa ditolerir (the intolerable form of child labor). ${ }^{19}$

Pada prinsipnya, penegakkan hukum perlindungan pekerja anak dan penegakkan hakhak anak sama dan sebangun keseluruhannya dengan prinsip - prinsip penegakan hukum pada umumnya. Sehingga implementasi dan penegakan hukum anak khususnya yang menyangkut aspek perlindungan hukum bagi anak- anak yang terpaksa bekerja / pekerja anak juga dipengaruhi oleh faktor- faktor berikut:

a. Faktor hukumnya

Dapat diidentifikasikan beberapa peraturan perundang- undangan tentang perlindungan anak pada umunnya yang ditertibkan setelah peratifikasian Konvensi Hak Anak yaitu:

1. Undang- Undang Nomor 13 Tahun 2003 tentang Ketenagakerjaan

2. Undang- undang Nomor 25 tahun 2002 tentang Perlindungan Anak

\footnotetext{
${ }^{19}$ Muhammad Joni dan Zulechaina Z, Tanamas. Aspek Hukum Perlindungan Anak dan Perspektif Konvensi Hakhak Anak, Bandung: Citra Aditya Bakti, 1999. hal. 8.
} 
3. Undang- undang Nomor 1 Tahun 2000 tentang Konvensi ILO

4. Undang- Undang Nomor 23 Tahun 1997 tentang Peradilan Anak

5. Undang- undang Nomor 20 Tahun 1999, tentang Konvensi ILO No. 138

6. Undang- undang Nomor 4 Tahun 1979 tentang Kesejahteraan Anak

b. Faktor Penegak Hukumnya

Para petugas atau lembaga yang bertanggung jawab atas berlangsungnya (terlaksananya) hukum dalam masyarakat harus benar- benar merupakan sumber daya manusia yang mau dan mampu memahami hukum anak, hak- hak anak serta memiliki kualitas pendidikan dan keahlian manajerial untuk menegakkan hukum anak dan hak- hak anak baik itu dari lembaga penyidik (kepolisian) penuntut (kejaksaan) hakim (peradilan) maupun lembaga advokasi pengacara/ penasehat hukum.

c. Faktor sarana dan fasilitas hukum

Sarana dan fasilitas untuk menegakkan hukum anak, khususnya terkait dengan perlindungan hukum bagi pekerja anak seyogyanya juga berpedoman pada ketentuanketentuan tentang sarana dan fasilitas hukum yang harus ada dalam upaya memberikan perlindungan hukum bagi pekerja anak yang disemangati oleh kehendak untuk mewujudkan hak-hak anak.

\section{a. Faktor Masyarakat Hukumnya}

Masyarakat merupakan wadah dinamika hukum dalam perilaku kehidupan sehari- hari yang lebih merujuk pada kondisi pada sejauh mana kepedulian masyarakat terhadap pekerja anak dan sejauh mana pula kepatuhan masyarakat terhadap ketentuan- ketentuan hukum yang mengatur/ mewajibkan adanya perlindungan hukum bagi pekerja anak, sebagai manifestasi pengakuan hukum anak dan hak- hak anak.

b. Faktor Budaya Hukumnya

Yaitu terkait dengan pandangan masyarakat atau nilai- nilai yang berakar dalam menegakkan hukum sebagai pedoman perilaku keseharian dan keyakinan masyarakat terhadap itikad penegak hukum dalam rangka mengupayakan perlindungan hukum bagi pekerja anak serta mewujudkan hak- hak anak. 
Salah satu upaya untuk melakukan penegakkan hukum perlindungan pekerja anak yaitu dengan melaksanakan secara konsisten tujuan Petunjuk Pelaksanaan Penanggulangan Pekerja Anak ( selanjutnya disingkat PPA) yaitu:

a. Melarang, mengurang dan menghapus pekerja anak yang hidup di pedesaan dan perkotaan

b. Membina, melindungi dan mengembangkan ekonomi orang tua pekerja anak.

c. Membina generasi penerus bangsa yang handal, maju, mandiri, sehat jasmani, rohani dan sejahtera

d. Mengubah sikap orang tua untuk tidak memperkerjakan anak atau menyuruh anak menjadi pekerja, khususnya yang bermjur dibawah 15 tahun

e. Meningkatkan pemahaman masyarajat tentang pengaruh buruk dan dampak negatif pekerjaan berat dan berbahaya bagi pekerja anak, serta pentingnya wajib belajar 9 tahun.

\section{Bentuk Perlindungan Hukum Terhadap Pekerja Anak Di Indonesia Berwawasan} Gender

Perlindungan Pekerja anak diatur dalam berbagai aturan yang berbicara mengenai tenaga kerja anak yang telah ada sejak dahulu sebagai salah satu usaha yang dilakukan untuk mengurangi dan menghapus adanya pekerja anak di Indonesia.

Salah satu aturan yang diberlakukan yaitu Undang- Undang Nomor 1 tahun 1961 dimana dalam undang- undang yang dimaksud dengan anak adalah anak yang berusia 8-14 tahun. Anak yang masih dalam kategori anak ini dilarang untuk bekerja. Namun ketentuan ini masih belum berlaku karena belum ada peraturan pelaksananya. Hingga untuk mengisi kekosongan hukum dengan terpaksa diberlakukanlah ketentuan lama yaitu Stbl 1925 No. 647 tentang Pembatasan Pekerja Anak dan Wanita pada malam hari.

Kemudian setelah Indonesia meratifikasi Konvensi ILO Nomor 38 mengenai Usia Minimum untuk diperbolehkan bekerja melalui Undang- undang Nomor 10 tahun 1999 menyatakan bahwa usia boleh bekerja jika sudah lebih dari 15 tahun.

Selain dari Konvensi ILO Nomor 138 dan Konvensi ILO Nomor 139, diatur juga ke dalam Konvensi ILO Nomor 182 mengenai Pelarangan dan Tindakan Segera untuk Penghapusan bentuk-bentuk pekerjaan terburuk untuk anak (Convension Concerning the Prohibition And Immediate Action For The Elimination of the Worst Form of Child Labour) yang diratifikasi Pemerintah Indonesia pada tanggal 8 Maret 2000 dengan UU No. 1/2000.

Untuk mengatasi masalah pekerja anak ini ada tiga pendekatan yang dapat digunakan, yaitu penghapusan (abolition), perlindungan (protection), dan pemberdayaan (empowerment). 
Pendekatan abolisi mendasarkan pemikirannya pada bahwa setiap anak tidak boleh bekerja dalam kondisi apapun, hal ini karena anak punya hak yang seluas-luasnya untuk bersekolah dan bermain, serta mengembangkan dirinya seoptimal mungkin.

Sementara pendekatan perlindungan (protection) mendasarkan pemikirannya pada jaminan terhadap hak sipil yaitu bahwa sebagai manusia dan sebagai warga negara setiap anak punya hak untuk bekerja. Dan pendekatan pemberdayaan (empowerment) sebenarnya merupakan lanjutan dari pendekatan proteksi, yang mengupayakan pemberdayaan terhadap pekerja anak agar mereka dapat memahami dan mampu memperjuangkan hak-haknya. Pada dasarnya ILO didukung di beberapa negara termasuk Indonesia secara terus-menerus mengupayakan pendekatan abolisi atau penghapusan terhadap segala bentuk pekerja anak.

Dalam Undang-undang Nomor 20 Tahun 1999 tentang Ratifikasi ILO Convention No. 138 Concerning Minimum Age for Admission to Employment the Abolition of Forced Labour atau Konvensi ILO No. 138 Mengenai Usia Minimum Untuk Diperbolehkan Bekerja Tahun 1973. Konvensi ini telah diadopsi oleh konferensi umum ILO pada tanggal 26 Juni 1973, dan Indonesia telah meratifikasi konvensi ini melalui Undang-undang Nomor 20 Tahun 1999. Konvensi ini sendiri, seperti yang tercantum dalam alinea keempat pembukaannya, dimaksudkan untuk menetapkan suatu naskah umum mengenai batasan umur yang secara berangsur-angsur akan menggantikan naskah-naskah yang ada yang berlaku pada sektor ekonomi yang terbatas. Hal ini karena sebelumnya memang sudah ada rumusan tentang batasan umur minimal untuk bekerja, hanya saja rumusan itu berbeda-beda untuk setiap jenis dan sektor kerja. Alinea keempat pembukaan ini juga menyebutkan bahwa tujuan dari konvensi ini sendiri adalah untuk menghapus anak sebagai pekerja pada kegiatan ekonomi secara keseluruhan.

Beberapa muatan asas yang berkaitan dengan perlindungan anak terhadap eksploitasi anak sebagai pekerja dalam konvensi ini adalah pada asas perlindungan, asas pencegahan, asas penerapan secara efektif, dan asas kerja sama nasional. Konvensi ini juga memuat norma-norma yang berkaitan langsung dengan konsep perlindungan anak sebagai pekerja. Pasal 1 mewajibkan negara anggota untuk mengambil tindakan segera dan efektif untuk menjamin pelarangan dan penghapusan bentuk-bentuk terburuk kerja anak sebagai hal yang mendesak.

Dari penjelasan di atas terlihat bahwa perlindungan anak dari eksploitasi ekonomi merupakan bagian dari hak terhadap kelangsungan hidup (survival rights). Lebih lanjut konvensi juga menentukan langkah-langkah yang harus diambil, yaitu antara lain; menentukan umur minimum atau umur-umur minimum untuk ijin bekerja, menetapkan 
peraturan-peraturan yang tepat mengenai jam-jam kerja dan syarat-syarat perburuhan, dan menentukan hukuman atau sanksi-sanksi lain yang tepat untuk menjamin pelaksanaannya yang efektif.

Sebagaimana telah diketahui, bahwa masalah yang terkait dengan pekerja anak adalah masalah lintas sektoral, yang meliputi aspek ekonomi (anak bekerja merupakan salah satu faktor yang mempengaruhi produktivitas sebuah keluarga), kemudian dari segi budaya (anak bekerja merupakan 'keharusan' budaya masyarakat tertentu yang merupakan doktrin Jawa 'banyak anak banyak rezeki'), politik (dengan anak bekerja, dapat diharapkan dapat melanggengkan dominasi trah/kekuasaan), hukum (anak yang bekerja juga melingkupi penegasan status dan kedudukan anak sebagai subyek yang memiliki hak dan kewajiban yang harus dijamin oleh hukum), sosial (anak yang bekerja dapat mengangkat harkat dan derajat sebuah keluarga di mata masyarakat/ anak yang menganggur adalah hina di mata masyarakat). Sehingga berpijak dari berbagai macam perspektif masalah anak yang bekerja tersebut, menuntut pula regulasi dan pengaturan yang komprehensif dalam bentuk peraturan perundangan yang seharusnya dibuat, baik oleh eksekutif maupun legislatif, baik di tingkat pusat maupun di tingkatan daerah, selaras dengan semangat dan esensi otonomi daerah.

Secara konsepsional, setidaknya ada tiga pendekatan dalam memandang masalah pekerja anak, yang sekiranya dapat dipergunakan sebagai upaya untuk mengatasi dan sekaligus memberdayakan pekerja anak, yakni penghapusan (abolition), perlindungan (protection), dan penguatan atau pemberdayaan (empowerment).

Pendekatan penghapusan muncul berdasarkan asumsi bahwa seorang anak tidak boleh bekerja, karena dia harus sekolah dan bermain. Pendekatan perlindungan, muncul berdasarkan pandangan bahwa anak sebagai individu mempunyai hak untuk bekerja. Oleh karenanya hak-haknya sebagai pekerja harus dijamin melalui peraturan ketenagakerjaan sebagaimana yang berlaku bagi pekerja dewasa, sehingga terhindar dari tindak penyalahgunaan dan eksploitasi. Sedangkan pendekatan Empowerment, juga berangkat dari pengakuan terhadap hak-hak anak dan mendukung upaya penguatan pekerja anak agar mereka memahami dan mampu memperjuangkan hak-haknya.

Selain memperhatikan ketiga pendekatan tersebut di atas, upaya memberikan perlindungan dan pencegahan terhadap pekerja anak dapat dilakukan dengan cara; pertama, mengubah persepsi masyarakat terhadap pekerja anak, bahwa anak yang bekerja dan terganggu tumbuh kembangnya dan tersita hak-haknya akan pendidikan tidak dapat dibenarkan. Kedua, melakukan advokasi secara bertahap untuk mengeliminasi pekerja anak, 
dengan perhatian pertama diberikan kepada jenis pekerjaan yang sangat membahayakan, dalam hal ini perlu ada kampanye besar-besaran untuk menghapuskan pekerja anak. Ketiga, mengundangkan dan melaksanakan peraturan perundang-undangan yang selaras dengan konvensi internasional, khususnya Konvensi Hak Anak dan Konvensi ILO lain yang menyangkut anak, keempat, mengupayakan perlindungan hukum dan menyediakan pelayanan yang memadai bagi anak-anak yang bekerja di sektor informal, seperti di tempat pembuangan akhir (TPA) sampah. Kelima, memastikan agar anak-anak yang bekerja memperoleh pendidikan dasar 9 tahun, pendidikan keterampilan melalui bentuk-bentuk pendidikan alternatif yang sesuai dengan kebutuhan mereka.

Pada umumnya, upaya perlindungan terhadap pekerja anak berbeasis gender dapat dibagi menjadi perlindungan langsung dan tidak langsung. Upaya-upaya perlindungan secara langsung di antaranya meliputi: pengadaan sesuatu perlakuan khusus agar pekerja anak perempuan terlindungi dan diselamatkan dari sesuatu yang membahayakannya, pencegahan dari segala sesuatu yang dapat merugikan atau mengorbankan pekerja anak perempuan, pengawasan, penjagaan terhadap gangguan dari dalam dirinya atau dari luar dirinya, pembinaan (mental, fisik, sosial), pemasyarakatan pendidikan formal dan informal dalam hal ketrampilan kerja yang sesuai dengan kodrat laki- laki dan perempuan, pengganjaran (reward) terhadap prestasi kerja, serta pengaturan dalam peraturan perundang-undangan yang membedakan perlakuan khusus bagi pekerja anak laki- laki dan perempuan. Hal ini dilakukan karena melihat kebutuhan dan kemampuan kerja anak laki-laki dan perempuan berbeda begitu pula dalam hal pekerjaan.

Sedangkan, upaya perlindungan tidak langsung antara lain meliputi: pencegahan melaui orang lain, yaitu memalui pemerataan kesempatan kerja terhadap orang tua sehingga ketika orang tua dapat memenuhi kebutuhan dalam keluarga maka jumlah pekerja anak juga akan semakin berkurang, peningkatan pengertian bagi para orang tua yang tepat mengenai manusia anak serta hak dan kewajibannya, penyuluhan mengenai pembinaan anak dan keluarga, pengadaan sesuatu yang menguntungkan anak, pembinaan (mental, fisik dan sosial) para partisipan selain anak yang bersangkutan dalam pelaksanaan perlindungan anak, penindakan mereka yang menghalangi usaha perlindungan anak. Memberikan sarana pendidikan gratis berupa beasiswa sehingga anak dapat mengenyam pendidikan dalam usia wajib belajar. Dalam hal pendidikan ini juga perlu adanya pemahaman bagi orang tua bahwa perempuan dan laki-laki mempunyai hak dan kesempatan yang sama untuk mendapatkan akses pendidikan. 


\section{Kesimpulan}

Perlindungan terhadap anak sebenarnya telah terintegrasi dalam hukum nasional yang terkandung dalam KUHPerdata, KUHPidana, dan sejumlah peraturan perundang- undangan tentang perlindungan anak. sebagai upaya untuk menegakkan perlindungan hukum bagi pekerja anak setidaknya ada lima faktor yang harus dikuatkan yaitu diantaranya faktor hukum, faktor penegak hukum, faktor sarana dan fasilitas hukum, faktor masyarakat hukum, faktor budaya hukum.

Bentuk perlindungan hukum terhadap pekerja anak di Indonesia berwawasan gender selain sudah ada banyak peraturan perundang- undangan yang ada di Indonesia untuk memberikan perlindungan hukum terhadap anak yang bekerja ada hal- hal lain yang harus lebih ditekankan karena pada kenyataanya pelaksanaan peraturan perundang- undangan masih banyak kekurangan. Untuk mengatasi masalah pekerja anak ini ada tiga pendekatan yang dapat dilakukan yaitu penghapusan (abolition), perlindungan (protection), dan pemberdayaan (empowerment) dengan memperhatikan tiga asas yaitu asas pencegahan, asas penerapan secara efektif dan asas kerjasama nasional. Dalam hal ini terdapat lima langkah yang mnejadi prioritas yaitu pertama, mengubah persepsi msyarakat terhadap pekerja anak, kedua, melakukan advokasi secara bertahap untuk mengeliminasi pekerja anak, ketiga, mengundangkan dan melaksanakan peraturan perundang- undangan bagi perlindungan pekerja anak yang berwawasan gender analisis, keempat, mengupayakan perlindungan hukum dan menyediakan pelayanan yang memadai bagi abak- anak, dan kelima memastikan agar anak- anak yang bekerja memperoleh pendidikan dasar 9 tahun. Dari semua bentuk perlindungan terhadap pekerja anak berwawasan gender tersebut secara umum dapat dibagi menjadi perlindungan langsung dan tidak langsung.

\section{DAFTAR PUSTAKA}

Astuti, Made Sadhi. Hukum Pidana Anak Dan Perlindungan Anak, Malang: UM Press.2003

Atmasasmita, Romli. problema kenakanlan anak-anak remaja (yuridis sosio kriminologis). Bandung: armico. 1983

Djumialdji. Perjanjian Kerja. Jakarta: Bumi Aksara. Jakarta. 1997

Gosita, Arif. Masalah korban kejahatan. Jakarta:Akademika Pressindo. 1983

Hadjon, Philipus M. Pengantar hukum administrasi indonesia. Yogyakarta: Gajah Mada University press. 2002 
Hastadewi, Yuli. Pekerja anak pada beberapa sektor di Tulungagung dan Probolinggo Jawa Timur, Jakarta: Unicef Indonesia. 2003

Hariadi, Sri Sanituti \& L.A. Salim.. Pekerja anak di sektor berbahaya: perempuan lebih sengsara, dalam buku Pekerja Anak di Sektor Berbahaya. Surabaya: Lutfansah Mediatama. 200

Ibrahim, Johnny. Teori dan Metodologi Penelitian Hukum Normatif. Malang : Bayumedia Publishing. 2010

Joni, Muhammad dan Zulechaina Z, Tanamas. Aspek Hukum Perlindungan Anak dan Perspektif Konvensi Hakhak Anak. Bandung: Citra Aditya Bakti. 1999

Kartono, Kartini. gangguan-gangguan psikis. Bandung: Sinar Baru. 1981

Marzuki, Peter Mahmud. Penelitian Hukum. Jakarta: Kencana. 2005

Poerwanto, Helena. Hukum Perburuhan Bidang Kesehatan Dan Keselamatan Kerja , cet. ke 1. Jakarta: FHUI. 2005

Putranto. (11 Januari 1992). Perbincangan seputar anak. Diambil pada tanggal 7 September 2009, dari http://www.S.S.net.com/humana/bab2

R.A. Koesnoen, Susunan Pidana Dalam Negara Indonesia. Bandung: Sumur. 1964

Raharjo, Satjipto. Ilmu Hukum. Bandung:Citra Aditya Bakti. 1991

Soemitro. Aspek Hukum Perlindungan Anak. Jakarta: Bumi Aksara1990

Soepomo, Iman. Hukum Perburuhan Bidang Hubungan Kerja. Jakarta: Djambatan, Jakarta. 1983

Sudjono, Saukarto, Marmo. Penegakan hukum dinegara pancasila. Jakarta: Garuda Metropolis perss. 1997

Survey Kesejahteraan Nasional / Susenas. Jakarta: Biro Pusat Statistik (BPS).2004

Suyanto, Bagong. Pekerja Anak dan Kelangsungan Pendidikannya. Surabaya: Airlangga University Press. 2003

Usman, Hardius dan Nachrowi D Nachrowi, Pekerja Anak di Indonesia, Jakarta: PT Gramedia Widiasarana. 2004. 
